\title{
Seasonal and Spatial Variation of BTEX in Ambient Air of Delhi
}

\author{
Rina Singh ${ }^{*}$, Manisha Gaur ${ }^{2}$, Anuradha Shukla1 \\ ${ }^{1}$ Environmental Science Division, CSIR-CRRI, New Delhi, India \\ ${ }^{2}$ Environmental Science Division, AcSIR-CRRI, New Delhi, India \\ Email: "rina_it@rediffmail.com
}

Received 2 February 2016; accepted 15 April 2016; published 18 April 2016

Copyright (C) 2016 by authors and Scientific Research Publishing Inc. This work is licensed under the Creative Commons Attribution International License (CC BY). http://creativecommons.org/licenses/by/4.0/

(c) (i) Open Access

\section{Abstract}

The present study aims to provide an indication of ambient levels of BTEX in the immediate vicinity of petrol filling stations in Delhi \& other road side corridors of Delhi. In this study spatial and seasonal variation of BTEX has been measured at different locations in Delhi. For the measurement of VOCs, passive based diffusion methodology was adopted for the adsorption of BTEX over the activated charcoal. Four categories of sampling sites were chosen (residential, traffic junctions, road side corridors and petrol pumps). The result confirms that the aromatic concentrations in the ambient air of gas stations are appreciably higher than the average values in locations with high vehicular flux. The mean concentration of BTEX at all the locations was $0.622 \mu \mathrm{g} / \mathrm{m}^{3}, 0.361$ $\mu \mathrm{g} / \mathrm{m}^{3}, 1.037 \mu \mathrm{g} / \mathrm{m}^{3}$ and $0.122 \mu \mathrm{g} / \mathrm{m}^{3}$. The average concentration of benzene was highest at petrol pump $3.5 \mu \mathrm{g} / \mathrm{m}^{3}$ however at all other sampling sites it was in the range of 0.294 to $0.712 \mu \mathrm{g} / \mathrm{m}^{3}$. The mean concentration value shows that the xylene concentration dominates more in Delhi as compared to benzene. The total average BTEX concentration at road side corridors was 0.594 $\mu \mathrm{g} \cdot \mathrm{m}^{-3}$, at residential corridors was $0.262 \mu \mathrm{g} \cdot \mathrm{m}^{-3}$, at intersections it was $0.649 \mu \mathrm{g} \cdot \mathrm{m}^{-3}$ and at petrol filling stations it was $1.457 \mu \mathrm{g} \cdot \mathrm{m}^{-3}$. The concentration was in the order of petrol filling stations $>$ intersections $>$ road side corridors $>$ residence. These data show the predominance of diesel driven vehicles in Delhi since xylene mainly comes from diesel exhausts. The influential voc species in case of diesel engine exhaust are benzene, ethylbenzene, xylenes, propane, $n$-decane and undecane and in case of gasoline vehicle exhaust influential species are benzene, ethylbenzene, 1,2,4-methylbenzene, 1,3,5-methylbenzene, $n$-hexane and 2-methylhexane. So xylene is mainly coming from diesel exhaust since gasoline vehicle exhaust doesn't show this species.

\section{Keywords}

Vocs, Benzene, Toluene, Xylene, Ethylbenzene

${ }^{*}$ Corresponding author. 


\section{Introduction}

Delhi's traffic emits a lot of poisonous and harmful gases that we inhale every day. The air pollution in Delhi has risen to the toxic levels and therefore the people and the government of Delhi need to do something urgently to reduce it to its safe level. The capital not only has the worst air quality among the big cities across the world, a new study conducted by Central Pollution Control Board (CPCB) has found alarmingly high levels of a carcinogenic volatile organic compound (VOC) called benzene, in Delhi's air. The average benzene level in Delhi has been found to be $14 \mu \mathrm{g} / \mathrm{m}^{3}$, which is almost three times higher than its safe limit of $5 \mu \mathrm{g} / \mathrm{m}^{3}$ [1]. The Capital is so polluted that individuals with a breathing problem are vulnerable to a sudden asthma attack. Inhaling carcinogenic benzene can fatally affect heart, lungs, respiratory tracts, brain, bones and blood cells [2]. The Capital city is under pollution threat and if we don't fix it, the poisonous air will kill us and if it continues to be like this, by 2050 Delhi will be the worst victim of air pollution. The heavy traffic on the Ring Road and Outer Ring Road, and the diesel emissions from trucks are the primary causes for polluting Delhi's air. In the last couple of years, sale of diesel vehicles has gone up from $18 \%$ to $62 \%$, and consequently the level of benzene and other harmful (toluene) and photochemically active VOCs (xylene, ethylbenzene) in the air has got increased [3].

In terms of air pollution measurements there are various literatures available on criteria pollutants, such as sulphur dioxide $\left(\mathrm{SO}_{2}\right.$ ), (Nitrous oxide) $\mathrm{NO}_{\mathrm{x}}$, (Suspended Particulate Matter) SPM, Carbon Monoxide (CO) and ozone $\left(\mathrm{O}_{3}\right)$ all over the world. However, non-methane volatile organic compounds (NMVOCs) are not monitored and have not received attention, particularly in India. VOCs are organic species with very high vapour pressure in the earth's atmosphere [4]-[6]. Their presence leads to photochemical oxidation causing increased smog episodes, ground level ozone concentrations and they are harmful to the ecosystem. Since Delhi is going through major smog problem recently, so the elevated concentration of VOCs in the ambient air of Delhi may be one of the reasons for this. At concentrations found in the urban environment, many VOCs have been reported to be toxic, carcinogenic or mutagenic. There are more than hundreds of VOCs found in urban atmospheres such as benzene (B), toluene (T), ethylbenzene (E), xylene (X), formaldehyde (F) and polynuclear aromatic hydrocarbons (PAHs) which are grouped in the category of potential carcinogens and poses a high risk to public health [4]. Among VOC pollutants, special attention is paid to BTEX species especially benzene. The main source of BTEX in urban areas is gasoline evaporation and traffic emission [7]. Almost 90\% of benzene in ambient air comes from traffic [8]. According to findings by CSIR-Central Road Research Institute (CRRI), Delhi's eight most erratic traffic bottlenecks are wasting at least 40,000 kilolitres of fuel daily while vehicles wait in peak rush hours [9]. Due to the oil shortage and the resulting high price of oil, light-duty diesel vehicles (LDDVs) have become popular based on their lower fuel consumption and durability.

Despite advances in emission control technologies like designing of new catalytic converter for diesel and gasoline engines, vehicular pollution is still an important and major issue. Besides vehicular pollution, filling stations (petrol/diesel) in Delhi is also the major contributors to Delhi's air pollution. In Delhi most of the fuel stations are situated near residential/commercial area which also increases the vulnerability of people residing in this area over benzene and VOCs inhalation. Petrol pumps are a major source of toxic benzene emissions that make it one of the most lethal contributors to Delhi's air pollution problem. Benzene is formed during motor engine combustion process and emitted in the exhaust [10]-[12]. Apart from vehicle exhausts, evaporation from petrol stations can also shoot up the benzene levels [13] [14]. The evaporative emissions at these pumps release the maximum amount of benzene in the atmosphere and none of the pumps (very few) have a Vapour Recovery System mechanism like the ones in the western countries. So if we really want healthy and clean atmosphere, Vapour Recovery System has to be installed immediately in all the filling stations.

Benzene is a component of crude oil and petrol that can be harmful even at trace levels [14]. World Health Organization (WHO) and United Sates Environmental Protection Agency (USEPA) did not specify any threshold for benzene exposure. It has been classified as a human carcinogen by International Agency for Research on Cancer (IARC) and was listed by both the European Commission (EC) and the World Health Organization (WHO) as one of the top-priority compounds for the development of guidelines for both outdoor and indoor air quality. The main exposure route of benzene is inhalation, which accounts for $>99 \%$ of the total exposure of the general population [15]. The health effects of benzene are well known: like acute/short-term inhalation exposure of humans to benzene may cause drowsiness, dizziness, headaches, as well as eye, skin, and respiratory tract irritation, and, at high levels, unconsciousness [16]-[20]. Chronic (long-term) inhalation exposure has caused various disorders in the blood, including reduced numbers of red blood cells, anaemia, and even leukaemia of which the risk estimate was reported as " 24 excess deaths per one million persons for a lifetime exposure of $1 \mathrm{ppb}\left(\right.$ or $3.24 \mu \mathrm{g} \cdot \mathrm{m}^{-3}$ ) 
benzene” [21]. The recommended exposure limit of benzene for occupational settings has decreased continuously from 100 ppm in 1947 to 1 ppm; the 1-h average ambient air quality guideline in Alberta (Canada) is 9 ppb [14]. However, adverse health outcomes, including haematological changes and gene perturbations, have been reported at exposure levels even at below 1 ppm [14]. Doctor's link benzene to certain kinds of lymphomas, a cancer that begins in immune system cells called lymphocytes. The National Ambient Air quality standards set by Central Pollution Control Board (CPCB) for annual time weighted average limits for benzene is $5 \mu \mathrm{g} / \mathrm{m}^{3}$ [22] [23]. Till now CPCB has not set any standard for other photochemical active VOCs like Toluene, Ethylbenzene and Xylene.

The importance of an individual VOC on ozone formation depends on how quickly it reacts to form free radical species. Ozone formation potential of VOCs can vary by virtue of differences in their reactivity and structure. Two sets of reactivity factors "maximum incremental reactivity” (MIR) and "maximum ozone reactivity” (MOR) have been developed [24]. The MIR and MOR values have been adopted by the California Air Resources Board (CARB) for use in assessing the impact of alternate motor vehicle fuels. Similar analysis of VOCs will help India's VOC Management Plan to assess its strategies on the use of alternate fuels to minimize emissions in urban centers. This has led to the development of scales called “ozone formation potential” for VOC. Among the aromatic volatile hydrocarbons (benzene, toluene, ethylbenzene and xylenes), xylenes are considered the more reactive species with respect to ethylbenzene, whereas benzene has a lower reactivity and more stable in the atmosphere, due to its relatively longer lifetime [25]. Xylenes ((m, p)-xylene plus o-xylene) are the most dominant contributor to ozone formation among BTEX [25]. So we cannot ignore the fact that Xylene may be one of the reasons for enhanced ozone concentration in Delhi. Therefore knowledge of ambient levels of VOCs is necessary to evolve a proper strategy to control tropospheric ozone build up and maintain healthy air quality. Atmospheric behaviour of VOCs is governed to a large extent by their life time. Highly reactive species will react near the vicinity of the sources, while slow reacting species may be transported to large distances. Toluene has much shorter life time than benzene [11]. So, higher Benzene to Toluene $(\mathrm{B} / \mathrm{T})$ ratio will be found in aged air via a long range transport. B/T ratio can be thus used as a tracer to predict long range transport. However, if sources of benzene or toluene other than vehicular exhaust are present $\mathrm{B} / \mathrm{T}$ ratio cannot be considered as a tracer.

Source apportionment study using chemical mass balance (CMB) model carried out by Anjali et al. [26] indicate that emissions from diesel internal combustion engines dominate in Delhi. Diesel/gasoline internal combustion engines are major contributors to air quality [26]. The exhaust of gasoline and diesel automobiles contains significant concentrations of VOCs, the most important of which are benzene, 1 - 3 butadienes, m \& p-xylene, ethylbenzene, toluene and formaldehyde. Influential species in case diesel engine exhaust are benzene, ethylbenzene, xylenes, propane, n-decane and undecane and in case of gasoline vehicle exhaust influential species are benzene, ethylbenzene, 1,2,4-methylbenzene, 1,3,5-methylbenzene, n-hexane and 2-methylhexane [27]. Levels of benzene, toluene and xylene and ethyl benzene at few locations in some cities of India are available. Limited information is available on the spatial and temporal variability of VOCs in urban areas, more so this information for Indian cities does not exist. Lack of this information is a serious limitation for developing a pragmatic approach for air quality improvement in Delhi. Moreover, source attribution is also lacking, which is important for developing effective strategies to control VOC emissions. Some VOCs may be present at levels which are not considered hazardous to human health with short-term exposure, but are considered to have mutagenic or carcinogenic properties with long-term exposure. In order to understand the behaviour of air pollutants and the impact of such exposures on human health it is necessary to measure not only major VOCs, but also a number of minor compounds at low levels. Therefore knowledge of ambient levels of VOCs is necessary to evolve a proper strategy to control tropospheric ozone build up and maintain healthy air quality. The goal of this study is to investigate BTEX pollution in Delhi City and impacts of different traffic means on it.

\section{Methods and Materials}

Delhi is the capital of India. The state is spread over an area of $1483 \mathrm{~km}^{2}$. According to the Indian geography the state is located at the centre of the Indian subcontinent, amidst the ranges of Himalaya and the Aravalli. The latitudinal and longitudinal locations of Delhi are $23.38^{\circ} \mathrm{N}$ and $77.13^{\circ} \mathrm{E}$. The geographical location of this city influences the weather conditions of Delhi. Delhi experiences tropical steppe type of climate and hence its seasons are marked with extreme temperatures. It is very hot in summer (April-July) and cold in winter (NovemberJanuary). The average temperature during the summer can vary from $25^{\circ} \mathrm{C}$ to $45^{\circ} \mathrm{C}$ and during the winter it varies from $22^{\circ} \mathrm{C}$ to $5^{\circ} \mathrm{C}$. The spring season (Feb-March) temperature fluctuates from $20^{\circ} \mathrm{C}$ to $25^{\circ} \mathrm{C}$. The main seasonal climatic influence is that of monsoon, typically from mid of July to September with about $797.3 \mathrm{~mm}$ (31.5 
inches) of rain. During winter north westerly wind usually prevails, however, in June and July south-eas- terly wind predominates. The predominant wind direction in most part of the year is North-Westerly, except during the monsoon season (July to mid-September), when it is reversed to South-Easterly. The wind speed exhibits seasonal fluctuations, being maximum during the summer and monsoon months and in winter they are generally calm. Winter witnesses long periods of calm. Figure 1 shows the location of all the sampling sites taken for the study (marked in red circle).

\subsection{Passive Tube Sampling Methodology (Diffusive Sampling)}

To determine benzene and other non-polar volatile organic compounds (VOCs) like toluene, xylene and ethyl benzene, the samples are generally collected from the air on either an adsorbent or by trapping whole air in a container [28] [29]. Passive vapor monitors which collect VOCs based on diffusion are commonly used in occupational settings to measure ppm concentration levels present within the personal or breathing zone air [30] [31]. Passive or diffusive sampling of volatile organic compounds (VOCs) has gained interest in the last decades as can be seen from numerous research and review articles. Passive sampling may be defined as any sampling technique based on free flow of analyte molecules from the sampling medium to a collecting medium, as a result of a difference in concentration of the analyte between the two media. Net flow of analyte molecules from one medium to the other continues until equilibrium is established in the system or until the sampling session is

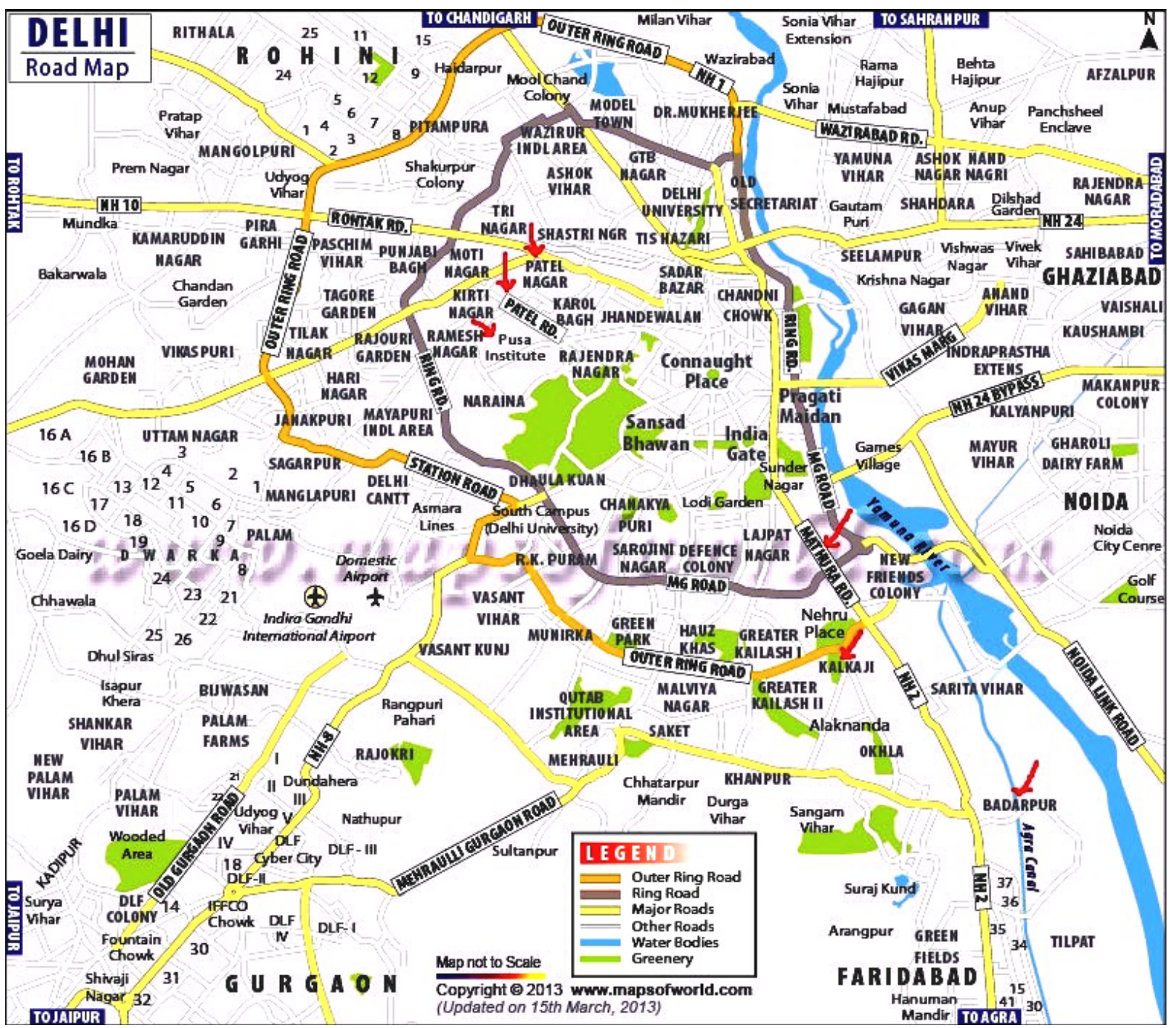

Figure 1. Road Map of Delhi showing approximate sampling sites (Pusa Institute, Patel Nagar, Kalkaji, Badarpur, Mathura Road). 
terminated by the user. The advantages of passive tube sampling are lower cost and greater work acceptability, as it does not require bulky and expensive pumps that are subjected to regular checking and possible error in flow rate [32] [33]. When applicable, it avoids the use of expensive and variable sample pumps and thus facilitates collection of large amounts of data required for accurate occupational hygienic assessments personal exposure measurements. A layer of adsorbent, typically activated charcoal, is covered with a barrier material whose outer surface is exposed to the contaminated air when sampling commences. The barrier prohibits bulk flow of air to the surface of the adsorbent. Since the adsorbent has a strong affinity for the contaminant, concentration gradient will be established which favors diffusion of the contaminant from the air to the adsorbent. The rate of diffusion is determined by the properties of the compounds and the sampler geometry. By judicious selection of the parameters controlling these factors, diffusive samplers may be used to integrate exposures over a full work shift such as an 8-h working day. Changing the geometry of the sampler allows continuous operation to be extended for a week and even a month.

In this work, we manually developed a passive sampling device for adsorption of volatile organic compounds (VOCs. For the fabrication of the sampling tubes, activated charcoal (40/60 mesh size, CDH Pvt Ltd.) was heated in an oven at $200^{\circ} \mathrm{C}$ overnight to facilitate the adsorbed compounds to escape and then cooled in a dessicator. The activated charcoal was then packed in glass tubes, $6 \mathrm{~mm}$ (diameter) $\times 80 \mathrm{~mm}$ (length) sealed from one side with a Teflon cap. The activated charcoal bed was supported by glasswool plugs on either side. The other side of the tube was left open and kept in the oven overnight at $250^{\circ} \mathrm{C}$ for the conditioning and then the other end of the tube was also sealed with Teflon cap. The tubes were then opened only at the sampling site. The sampling tubes were sealed after exposure. The sampling was carried out by exposing the fabricated diffusive sampling tubes in the ambient air for one week duration time for the month of Oct 2013, Nov 2013, Jan 2014, Feb 2014, March and May 2014 to obtain seasonal variability. A week-long passive sampling method adopted in the present study implies the average concentration of VOCs over a period of 1 week rather than projecting shortterm concentration-few hours-as reported in other studies. At each sampling site 2 sampling tubes, inclusive of one field blank were exposed at a height of $\sim 2$ to $3 \mathrm{~m}$. The activated charcoal samples were transferred from the sealed tubes into a glass vial and sealed immediately in order to prevent further adsorption of compounds and were stored at $4^{\circ} \mathrm{C}$ until analysis. To the sample vial $2 \mathrm{ml}$ of low-benzene carbon disulfide was added and shaken gently for $40 \mathrm{~min}$, immediately after this, a $2 \mathrm{ml}$ solution was withdrawn from the samples, including the blank samples, and injected into a Gas chromatography. Analysis was done by GC-FID (PerkinElmer Auto-XL) equipped with SE-54 fused silica column (30 m × $0.25 \mathrm{~mm}$ id (internal diameter)) and Total Chrome-Software. GC oven was programmed for $50^{\circ} \mathrm{C}$ hold for $4 \mathrm{~min}$ and ramped to $250^{\circ} \mathrm{C}$ at a rate of $10^{\circ} \mathrm{C} / \mathrm{min}$ with $10 \mathrm{~min}$ hold at $250^{\circ} \mathrm{C}$. Nitrogen was used as carrier gas with flow rate of $1 \mathrm{~mL} \cdot \mathrm{min}^{-1}$ and split ratio 1:10. VOCs were quantified using the external standard calibration procedure using VOC Standard (HC BTEX/MTBE Mix, $2000 \mu \mathrm{g} / \mathrm{ml}$ each in methanol) supplied by Supelco (Sigma Aldrich). Calibration standards were prepared by diluting the stock standard mixture. All solvents used for this study were of GR grade. To verify the validity and reproducibility of the data procured, some samples were chosen and their duplicate measurements were carried out. For laboratory, blank unexposed tube was also analyzed for BTEX similar to the exposed ones.

\subsection{Description of Sampling Sites}

Total eight sites were selected for passive sampling (Figure 1). About 76 samples were analyzed for total volatile organic compounds (VOCs), in connection with the seasonal variation, and spatial variation. However, for traffic variations two sites (Ashram intersection and Patel Chowk intersections), representing high and low traffic density, respectively, were selected. Traffic volume data not available for these sites and the values given here are guest estimates (GE) made on the basis of traffic volume data available for the year by localities nearby (Table 1).

\section{Traffic İntersection Sectors}

All the three sites are very busy traffic intersections. Monitoring was carried out at the kerbsides near traffic intersections. During peak hours, traffic jams are frequent in these locations. The sites are as follows:

1) Ashram Chowk: This area includes an extremely busy intersection with traffic lights on two, heavily used roads; the Ring Road and the Mathura Road. The traffic is slow moving and density is very high. In about 500 meters radius, there are 3 gasoline stations, commercial buildings, low-rise and high-rise residential buildings, small restaurants and waste water treatment facility. 
Table 1. Traffic density at different sites of Delhi. (CRRI Annual Report 2013-2014), [34].

\begin{tabular}{cccc}
\hline Categories & Site Name & Total traffic volumes (Nos) & Total Vehicles (PCUs) \\
\hline \multirow{2}{*}{ Intersections } & Ashram & 429,075 & 478,092 \\
& Patel Nagar Chowk & 173,835 & 232,961 \\
& Ashram colony & $429,075(\mathrm{GE})$ & NA \\
Residential & NPL colony & $173,835(\mathrm{GE})$ & NA \\
& Kalkaji & NA & NA \\
Petrol pumps & Badarpur pump & $429,075(\mathrm{GE})$ & NA \\
Road side corridors & CRRI Gate & $429,075(\mathrm{GE})$ & NA \\
\hline
\end{tabular}

2) Patel Chowk: The sampling site is situated on main road connecting Delhi with Jaipur near the traffic intersection (Dhaula Kuan). Patel Nagar’s neighboring areas are Baljit Nagar, Pusa Road, Rajendra Place, Karol Bagh, Inderpuri \& Naraina (a major industrial area). Air quality of the area is mainly influenced by the industries mostly of paints and varnishes; motor vehicle serving stations and electric motor winding, traffic load and generator sets due to frequent power failure.

3) Ring Road (Patel Nagar): This site is 400 to $500 \mathrm{~m}$ away from main Patel Chowk intersections.

\section{Road side corridors}

1) CRRI Gate: Situated on Delhi-Mathura Road (NH-2) which is an intercity road carrying high density traffic. This site is also surrounded by other industries like Okhla which is an industrial area with large traffic density of two wheelers and cars during office hours. Air quality of the area is mainly influenced by the industries and motor vehicle serving stations. Moreover there is a waste dumping site and sewage treatment plant in the vicinity of the sampling location. Traffic density is very high throughout the day. Vehicle composition consists of 2 and 3 wheelers, buses and cars during the day time while buses, cars and mainly heavy-duty trucks during the night hours. At all the sites, sampling was done at a distance of $50 \mathrm{~m}$ from the closest road.

2) NPL Gate: The monitoring has been conducted at N.P.L. premises, which is near to Pusa Road. The premise is approx. 100 meters away from the main road and surrounded with Govt. Offices. One side of this institute is covered with greenery. This site is 200 to $300 \mathrm{~m}$ away from the major intersection Patel Chowk.

\section{Petrol pump stations}

Sampling was carried out in the centre of petrol pump where vehicles halt for refueling. The selected site is:

1) Badarpur: The sampling was conducted at HP Petrol Pump behind Car Service Centre near the DTC bus stand and metal forging company.

\section{Residential sectors}

These sites are considered not to be directly influenced by heavy traffic roads. There are low-rise and high-rise residential buildings. There are densely residential villages, a hospital, diesel generators, a car garage and a gasoline station in about 500 meters radius. The different locations which are selected in this sector are typically residential and air quality is influenced mainly by domestic activities, vehicular movement, roadside traffic and waste treatment plant. The sites are as follows:

1) Kalkaji: It is a crowded market place in South Delhi. Air quality is mainly influenced by generator sets, vehicular movement, roadside eat outs and markets. There are densely residential villages, small shops, and a car garage in about 500 meter radius.

2) NPL Colony: It is a densely populated commercial and residential area which lies between two other busy commercial areas. The main road is narrow and congested. The traffic is heavy, slow, and mixed. This area is an extremely busy intersection of two, heavily trafficked roads, namely, the Ring Road, which is the main traffic artery of the city, and the Aurobindo Marg, which connects the city centre to the newly developed residential colonies.

3) CSIR Apartment: This site is adjacent to Ashram intersection. The traffic is slow moving and density is very high. This location is in the south part of Delhi about $0.5 \mathrm{~m}$ from the national highway. The area is adjacent to HPCL petrol pump also. 


\section{Background Station}

We selected one site as a background station. However, it is not a generally meaning background, but only less polluted compared with above mentioned stations at roadside and residential area. Laboratory blank: Zero air, which was obtained by passing compressed air in cylinder through a moisture trap and a VOC trap, was sampled with a pre-cleaned adsorbent tube in the laboratory in the same way as field sampling.

Field blanks: Three field blank samples were used to check if there was any possible contamination during sampling, transport and storage of air samples.

\section{Results and Discussion}

\subsection{Spatial Distribution and Variation of VOCs}

Figure 2 shows the typical spatial variation of BTEX at different locations in Delhi. At residential sector of NPL, Kalkaji and CSIR apartment, benzene was found in the range of $0.334-0.50 \mu \mathrm{g} / \mathrm{m}^{3}$, toluene in the range of $0.149-0.407 \mu \mathrm{g} / \mathrm{m}^{3}$, xylene from 0 to $1.232 \mu \mathrm{g} / \mathrm{m}^{3}$ and ethyl benzene from 0 to $0.101 \mu \mathrm{g} / \mathrm{m}^{3}$. At traffic intersections: Ashram, Patel Chowk and Ring Road Patel Chowk (this location was 200 to 300 meter away from the main intersection), benzene was in the range of 0.395 to $0.572 \mu \mathrm{g} / \mathrm{m}^{3}$, toluene was in the range of 0.244 to 0.348 $\mu \mathrm{g} / \mathrm{m}^{3}$, xylene in the range of 1.95 and $2.059 \mu \mathrm{g} / \mathrm{m}^{3}$ and ethyl benzene from 0 to $0.089 \mu \mathrm{g} / \mathrm{m}^{3}$. The mean concentration of BTEX at all the locations was $0.622 \mu \mathrm{g} / \mathrm{m}^{3}, 0.361 \mu \mathrm{g} / \mathrm{m}^{3}, 1.037 \mu \mathrm{g} / \mathrm{m}^{3}$ and $0.122 \mu \mathrm{g} / \mathrm{m}^{3}$. Xylene was dominant in the entire sampling sites except residential areas. The average concentration of benzene was highest at petrol pump $3.5 \mu \mathrm{g} / \mathrm{m}^{3}$ however at all other sampling sites it was in the range of 0.294 to $0.712 \mu \mathrm{g} / \mathrm{m}^{3}$. The mean concentration value shows that the xylene concentration dominates more in Delhi as compared to benzene. The dominance of xylene confirms that the contribution of xylene is mainly from traffic/ engine combustion process as 49\% vehicle in Delhi runs on either diesel or petrol [9].

Diesel internal combustion engine emissions, evaporative emissions of petrol, natural gas combustion and vehicular exhaust are the major contributors to the ambient levels of VOCs [11] [35]. Abundances of these compounds were substantially enriched over their abundances in the fuel, indicating that these compounds do not combust as well as other fuel components and they form as a part of the combustion process. Evaporated gasoline and liquid gasoline are the most abundant contributors in most areas for these VOCs [36]. Toluene, benzene and xylene dominated the aromatic VOC concentration in all the locations of Delhi and ethylbenzene was detected at very few locations, this may be due to its low life time and its high photochemical reactivity.

Benzene had an average and a maximum concentration of $0.622 \mu \mathrm{g} \cdot \mathrm{m}^{-3}$ and $3.451 \mu \mathrm{g} \cdot \mathrm{m}^{-3}$. Toluene had an

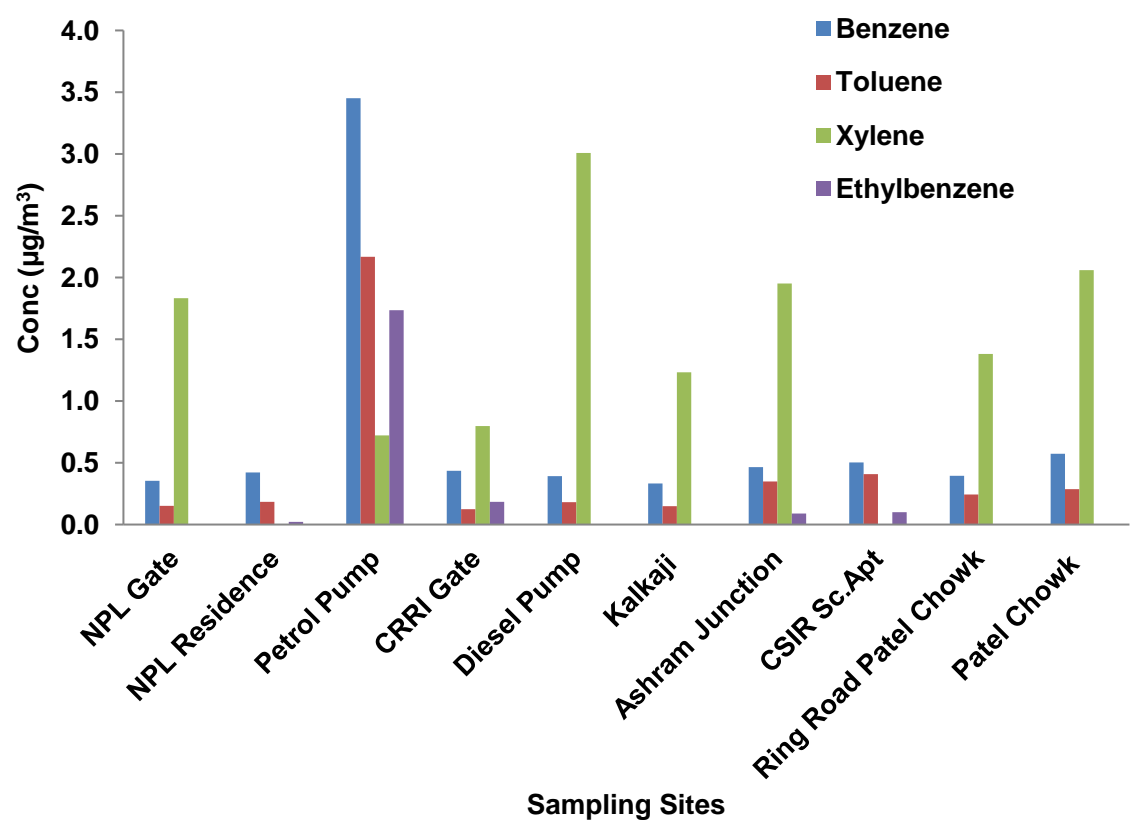

Figure 2. Typical spatial variation of BTEX at various sampling Sites of Delhi. 
average concentration of $0.361 \mu \mathrm{g} \cdot \mathrm{m}^{-3}$ and a maximum of $2.221 \mu \mathrm{g} \cdot \mathrm{m}^{-3}$. The xylene also had a fairly high concentration with a maximum of $3.398 \mu \mathrm{g} \cdot \mathrm{m}^{-3}$ and an average of $1.067 \mu \mathrm{g} \cdot \mathrm{m}^{-3}$. Table 2 summarizes the overall mean and maximum concentrations of the BTEX together with their standard deviations. The high standard deviation observed is because of the fact that the Figure is derived from the monthly average value obtained by pooling the VOC values of all the sites for individual months. The monthly values having high standard deviation are due to the inter-site variations in regard to traffic volume and local anthropogenic activities which are indicated in the individual site description. The highest concentration of most VOC species in terms of maximum and mean concentration was found in the fuelling stations. This is expected because the dominant source of benzene is car refueling. The concentrations at the road side corridors and traffic intersections followed.

The VOC concentrations in the residential district were at the lowest level. The spatial characteristics of the Delhi were further analyzed by dividing the entire region into four sub categories, namely the road side corridors (these locations were actually located 400 to $500 \mathrm{~m}$ away from the major traffic intersections), residential corridors, traffic intersections and refueling stations (Figure 3).

Table 3 shows the VOC concentrations in the four categories of sampling sites. The highest concentration of most VOC species in terms of maximum and mean concentration was found at the fuelling stations. For instance, benzene in the range of $0.398 \mu \mathrm{g} \cdot \mathrm{m}^{-3}$ to $1.922 \mu \mathrm{g} \cdot \mathrm{m}^{-3}$, toluene in the range of $0.136 \mu \mathrm{g} \cdot \mathrm{m}^{-3}$ to $1.173 \mu \mathrm{g} \cdot \mathrm{m}^{-3}$, $\mathrm{xy}-$ lene in the range of $0.308 \mu \mathrm{g} \cdot \mathrm{m}^{-3}$ to $1.866 \mu \mathrm{g} \cdot \mathrm{m}^{-3}$ and ethylbenzene in the range of $0.03 \mu \mathrm{g} \cdot \mathrm{m}^{-3}$ to $0.868 \mu \mathrm{g} \cdot \mathrm{m}^{-3}$. The total average BTXE concentration at road side corridors was $0.594 \mu \mathrm{g} \cdot \mathrm{m}^{-3}$, at residential corridors was $0.262 \mu \mathrm{g} \cdot \mathrm{m}^{-3}$, at intersections it was $0.649 \mu \mathrm{g} \cdot \mathrm{m}^{-3}$ and at petrol filling stations it was $1.457 \mu \mathrm{g} \cdot \mathrm{m}^{-3}$. The concentration was in the order of petrol filling stations $>$ intersections $>$ road side corridors $>$ residence.

The average toluene concentration in the refueling stations was $1.173 \mu \mathrm{g} \cdot \mathrm{m}^{-3}$, which was much higher than that at the intersections $\left(0.293 \mu \mathrm{g} \cdot \mathrm{m}^{-3}\right)$, residence $\left(0.270 \mu \mathrm{g} \cdot \mathrm{m}^{-3}\right)$ and road side corridors $\left(0.136 \mu \mathrm{g} \cdot \mathrm{m}^{-3}\right)$. The higher concentration of benzene $\left(0.438 \mu \mathrm{g} \cdot \mathrm{m}^{-3}\right)$ and toluene $\left(0.270 \mu \mathrm{g} \cdot \mathrm{m}^{-3}\right)$ at residence than road side corridors $\left(0.398 \mu \mathrm{g} \cdot \mathrm{m}^{-3}\right.$ and $\left.0.136 \mu \mathrm{g} \cdot \mathrm{m}^{-3}\right)$ may be because of the presence of petrol pump very near to this area and that

Table 2. Table: Mean Concentration of Benzene, Toluene, Xylene and Ethylbenzene for Various Locations in Delhi (ND: not detected).

\begin{tabular}{|c|c|c|c|c|c|c|c|c|}
\hline Locations & B & $\mathrm{T}$ & $\mathrm{T} / \mathrm{B}$ & $\mathrm{X}$ & $\mathrm{X} / \mathrm{B}$ & $\mathrm{E}$ & $\mathrm{X} / \mathrm{E}$ & BTXE \\
\hline NPL Gate & 0.353 & 0.151 & 0.428 & 1.831 & 5.187 & ND & - & 2.335 \\
\hline NPL Residence & 0.422 & 0.184 & 0.436 & 0 & 0.000 & 0.021 & - & 0.627 \\
\hline Petrol Pump & 3.451 & 2.166 & 0.628 & 0.723 & 0.210 & 1.736 & 0.416 & 8.076 \\
\hline CRRI Gate & 0.436 & 0.125 & 0.287 & 0.798 & 1.831 & 0.183 & 4.358 & 1.541 \\
\hline Diesel Pump & 0.392 & 0.18 & 0.459 & 3.008 & 7.673 & ND & - & 3.580 \\
\hline Kalkaji (indoor) & 0.334 & 0.149 & 0.446 & 1.232 & 3.689 & ND & - & 1.715 \\
\hline Kalkaji (outdoor) & 0.294 & 0.138 & 0.469 & 3.398 & 11.558 & ND & - & 3.830 \\
\hline Ashram Intersection & 0.466 & 0.348 & 0.747 & 1.95 & 4.185 & 0.089 & 21.910 & 2.853 \\
\hline CSIR Residence (Indoor) & 0.424 & 0.252 & 0.594 & 0 & 0.000 & 0.065 & - & 0.741 \\
\hline CSIR Residence (Outdoor) & 0.503 & 0.407 & 0.809 & 0 & 0.000 & 0.101 & - & 1.011 \\
\hline Ring Road Patel Chowk & 0.395 & 0.244 & 0.618 & 1.381 & 3.496 & ND & - & 2.020 \\
\hline Patel Intersection & 0.572 & 0.286 & 0.500 & 2.059 & 3.600 & ND & - & 2.917 \\
\hline Park Facing CSIR Res & 0.493 & 0.341 & 0.692 & 0 & 0.000 & ND & - & 0.834 \\
\hline Standard Dev & 0.756 & 0.488 & 0.134 & 1.101 & 3.297 & 0.430 & 11.443 & 2.775 \\
\hline $\operatorname{Max}\left(\mu \mathrm{g} / \mathrm{m}^{3}\right)$ & 3.451 & 2.166 & 0.809 & 3.398 & 11.558 & 1.736 & 21.910 & 10.751 \\
\hline $\operatorname{Min}\left(\mu \mathrm{g} / \mathrm{m}^{3}\right)$ & 0.294 & 0.125 & 0.287 & 0.000 & 0.000 & ND & 0.416 & 0.419 \\
\hline $\operatorname{Avg}\left(\mu \mathrm{g} / \mathrm{m}^{3}\right)$ & 0.641 & 0.364 & 0.538 & 1.109 & 2.756 & 0.137 & 8.895 & 2.252 \\
\hline
\end{tabular}




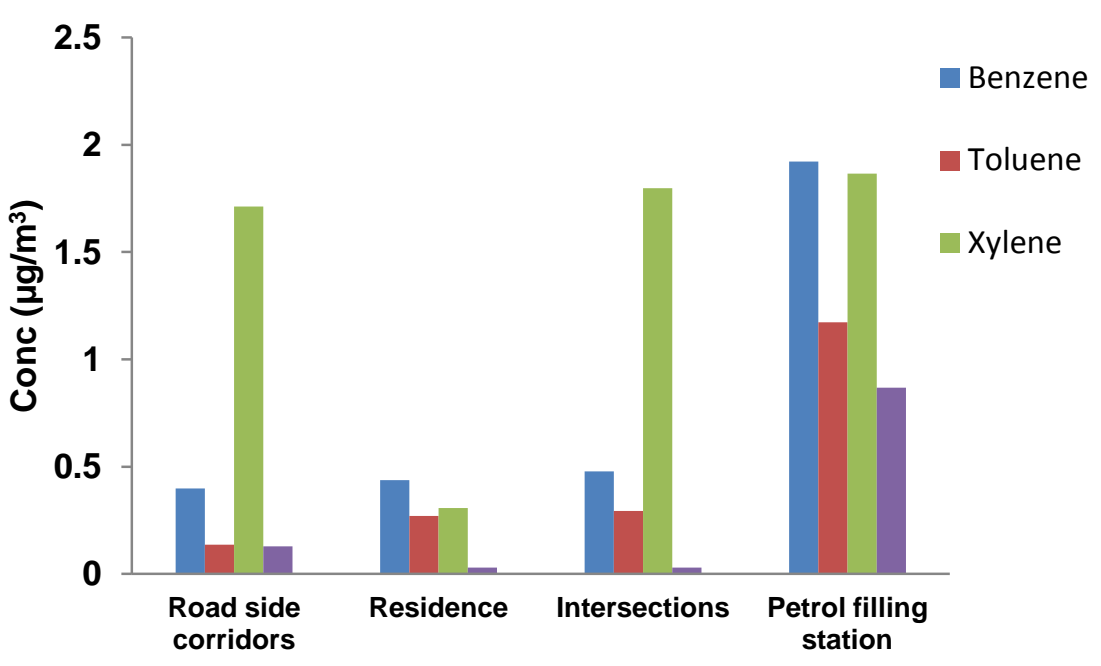

Figure 3. Variation of BTEX for the different categories of sampling.

Table 3. Average VOC Concentration and their Relative Ratios with Respect to Benzene, Toluene, Ethylbenzene and Xylene (BTEX).

\begin{tabular}{ccccc}
\hline & Benzene & Toluene & Xylene & Ethylbenzene \\
\hline Road side corridors & 0.398 & 0.136 & 1.713 & 0.128 \\
Residence & 0.438 & 0.270 & 0.308 & 0.031 \\
Intersections & 0.478 & 0.293 & 1.797 & 0.030 \\
Petrol filling station & 1.922 & 1.173 & 1.866 & 0.868 \\
Road side corridors & $\mathrm{T} / \mathrm{B}$ & $\mathrm{X} / \mathrm{B}$ & $\mathrm{X} / \mathrm{E}$ & 13.383 \\
Residence & 0.341 & 4.309 & 10.098 & \\
Intersections & 0.617 & 0.703 & 60.353 & \\
\hline
\end{tabular}

resulted in higher concentration of benzene and toluene at residential sector than road side corridors. However, xylene concentration was dominant at road side $\left(1.713 \mu \mathrm{g} \cdot \mathrm{m}^{-3}\right)$, traffic $\left(1.797 \mu \mathrm{g} \cdot \mathrm{m}^{-3}\right)$ and petrol filling stations $\left(1.866 \mu \mathrm{g} \cdot \mathrm{m}^{-3}\right)$ suggesting of some common source for all of them (Figure 4). Ethylbenzene was detected at petrol filling station $\left(0.868 \mu \mathrm{g} \cdot \mathrm{m}^{-3}\right)$, road side corridors $\left(0.128 \mu \mathrm{g} \cdot \mathrm{m}^{-3}\right)$, intersections $\left(0.030 \mu \mathrm{g} \cdot \mathrm{m}^{-3}\right)$ and residence $\left(0.031 \mu \mathrm{g} \cdot \mathrm{m}^{-3}\right)$. Ethyl benzene could not be detected at all the locations since it is very photo chemically active.

Atmospheric behaviour of VOCs is governed to a large extent by their life time. Highly reactive species will react near the vicinity of the sources, while slow reacting species may be transported to large distances. Table 3 summarizes the average VOC relative ratios and their standard deviations for the four sectors with respect to benzene, toluene, ethylbenzene and xylene (BTEX). According to mean concentrations of BTEX for each sampling points (Table 2) and spatial distribution (Figure 2 and Figure 3), the highest levels of BTEX were registered close to roads and with high-density traffic. In this study, the benzene concentrations in the high traffic roads were 3.5 to 9 times higher than in residential area. Benzene concentrations decrease rapidly in relation to the distance from the source (high-density traffic areas). This trend is also observed for other BTEX compounds emitted from traffic such as toluene, ethylbenzene, and xylenes. The higher concentration of xylene shows that all these sites are influence by heavy traffic (mainly diesel vehicles).

Research findings by University of Minnesota indicate that roadways generally influence air quality within a few hundred meters-about 500 - 600 feet downwind from the vicinity of heavily travelled roadways or along corridors with significant trucking traffic. This distance will vary by location and time of day or year, prevailing meteorology, topography, nearby land use, traffic patterns, as well as the individual pollutant [37]. So living 


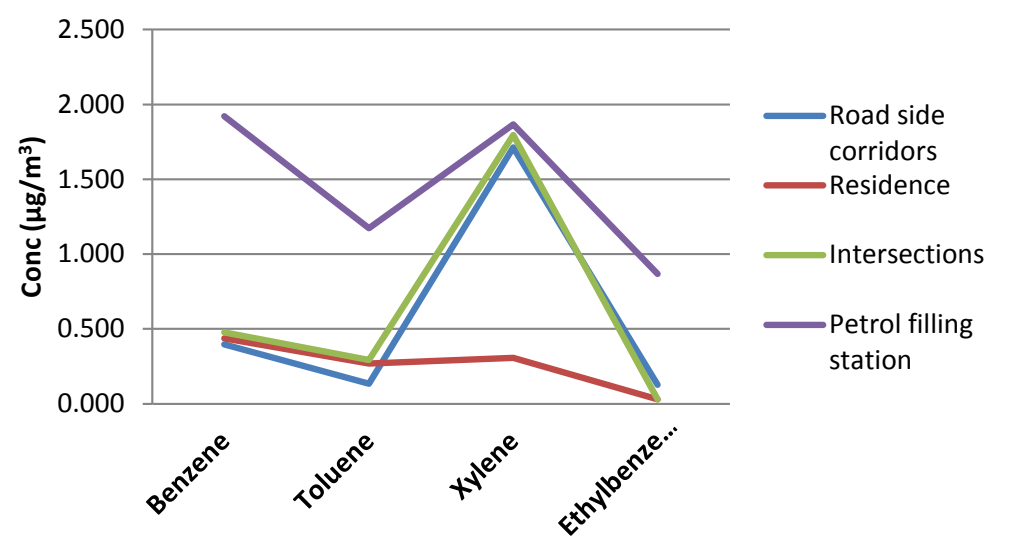

Figure 4. Variation of BTEX at sampling sites of Delhi.

near the highway may also up the risk of heart disease, according to this new research. Living 164 feet from a major road increased the risk of sudden cardiac death by 38 percent, compared to living 10 times farther away, researchers said. The risk increased 6 percent for every 328 feet closer the women lived to roadways.

Benzene is mainly emitted from vehicular combustion and toluene is released from both vehicular and industrial applications, therefore the toluene to benzene $(\mathrm{T} / \mathrm{B})$ ratio has been used to evaluate the relative importance of these two sources over the four sub-regions. The ratios between BTEX species have been widely used as an indicator to provide information about the different emission sources of these pollutants in the environment. The concentrations of relatively stable BTEX species (benzene and toluene, with atmospheric lifetimes of 12.5 and 2.0 days, respectively) gradually increase during daytime due to accumulation [11]. However, ethylbenzene and xylene concentrations, which are highly reactive in comparison with benzene and toluene, usually decrease in daytime due to photochemical reactions. In this study, toluene/benzene (T/B), xylene/benzene (X/B), and xylene/ ethylbenzene (X/EB) ratios were also investigated. T/B ratio approaching a value of 1 like Ashram Intersection and Patel Chowk Intersection indicates traffic-originated emission sources, and the value increases with the closeness of the pollution source. The interesting observation observed with this study is that the T/B ratio for CSIR residence value (0.809) was also very close to 1 suggesting the influence of traffic over this area [12] [38]. The residence is very close to major intersection area Ashram.

The highest T/B ratio was observed at locations: Ashram Intersection, CSIR Residence (outdoor), Ring Road Patel Chowk, Park Facing CSIR Residence and Petrol Pump which were 0.747, 0.809, 0.618, 0.692 and 0.628, respectively, which were larger than 0.6 indicating a strong contribution from vehicular emissions with a certain degree of photochemical process. The topography of this location is almost similar as all the locations are either at intersection or very close to major intersection. The T/B values were almost similar suggesting the common source of pollution i.e. vehicular/traffic. Table 2 shows that almost all VOC concentrations at the intersection site were markedly higher than those of the road side. These kinds of VOCs have been reported to be emitted from automobiles. The resemblance of T/B ratios of the roadside and intersection sites was because these VOCs might be emitted from vehicles and dilute due to advection and/or diffusion uniformly in the environment without considerable influence from stationary sources.

At sampling point CRRI Gate however, low X/B ratios was observed (0.287), which imply aging of the air mass and the effects of photochemical reactions. The lower value of $\mathrm{X} / \mathrm{B}$ at this location also indicates the influence of some other industrial sites near it suggesting this sub-region exhibited the characteristics of having both vehicular and industrial sources [39] [40]. The site is very close to waste dumping site, waste treatment plant, incinerator plant, and also surrounded by industrial region Okhla. Okhla is an industrial area with large traffic density of two wheelers and cars during office hours. Air quality of the area is mainly influenced by the industries mostly of paints and varnishes; motor vehicle serving stations and electric motor winding, traffic load and generator sets [4]. For site NPL Gate, NPL Residence, Kalkaji (indoor), Kalkaji (outdoor) and Diesel Pump the values were $0.428,0.436,0.446,0.469$ and 0.459 respectively. The ratios at both the locations were of the same magnitude and close to those obtained from automotive exhausts, indicating that the ambient BTEX originate mainly from motor vehicle emissions. The similar value here also indicates the presence of common source of pollution in this entire region. The interesting observation observed with this data is these areas are influence 
by mainly diesel source because the values are similar to that of X/B ratio for diesel source. The data also shows the predominance of xylene concentration in these areas. Study concluded by Anjali et al. [8] [13] also confirms that the diesel vehicle mainly dominates Delhi's traffic and the main species difference in both the gasoline and diesel vehicle exhaust is xylene where xylene mainly comes from diesel exhaust.

Figure 5 shows that the variation of BTEX at CRRI gate and NPL gate and the value of xylene are more at NPL gate as compared to CRRI gate. Figure 6 shows the variation of BTEX at all residential corridors and the xylene was detected only at Kalkaji residence. It is a crowded market place in South Delhi and the air quality is mainly influenced by generator sets which runs on diesel source and vehicular movement (both diesel and petrol). The presence of common diesel source in these areas would have contributed large concentration of xylene than benzene, toluene and ethylbenzene in these areas.

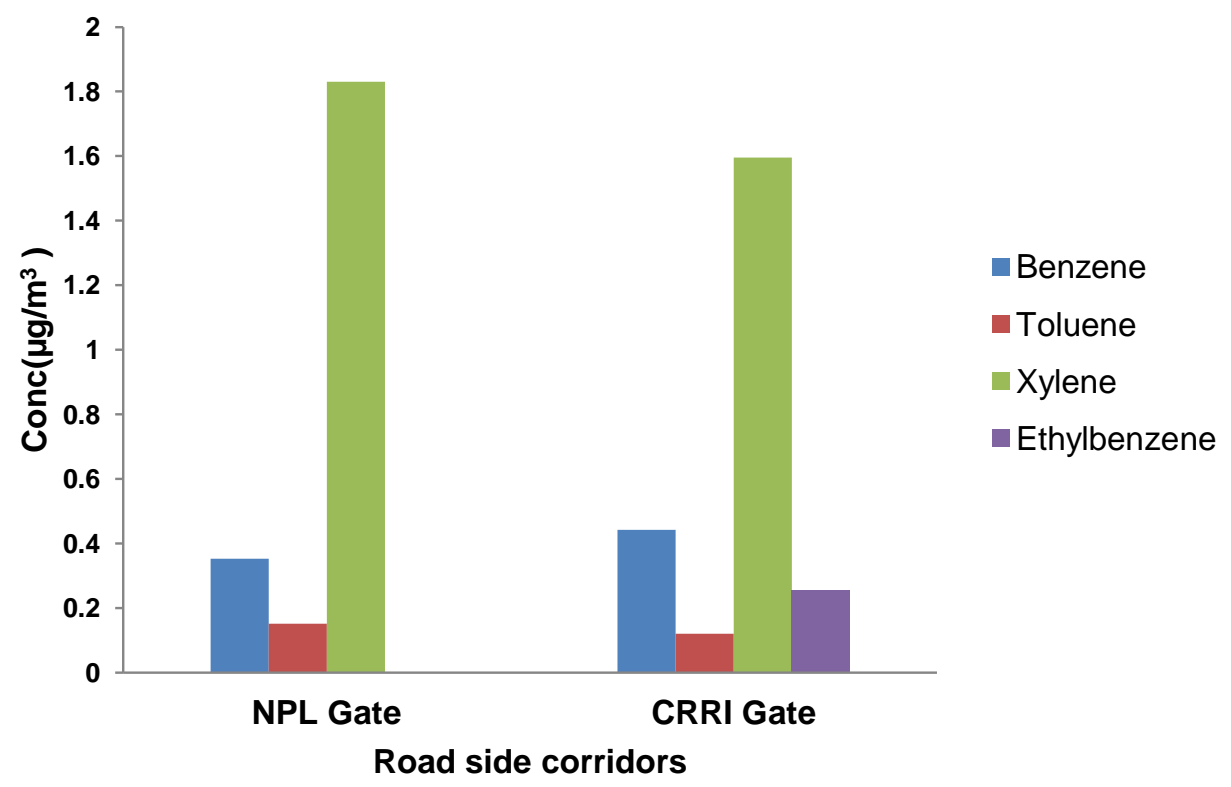

Figure 5. Variation of BTEX at NPL and CRRI gate.

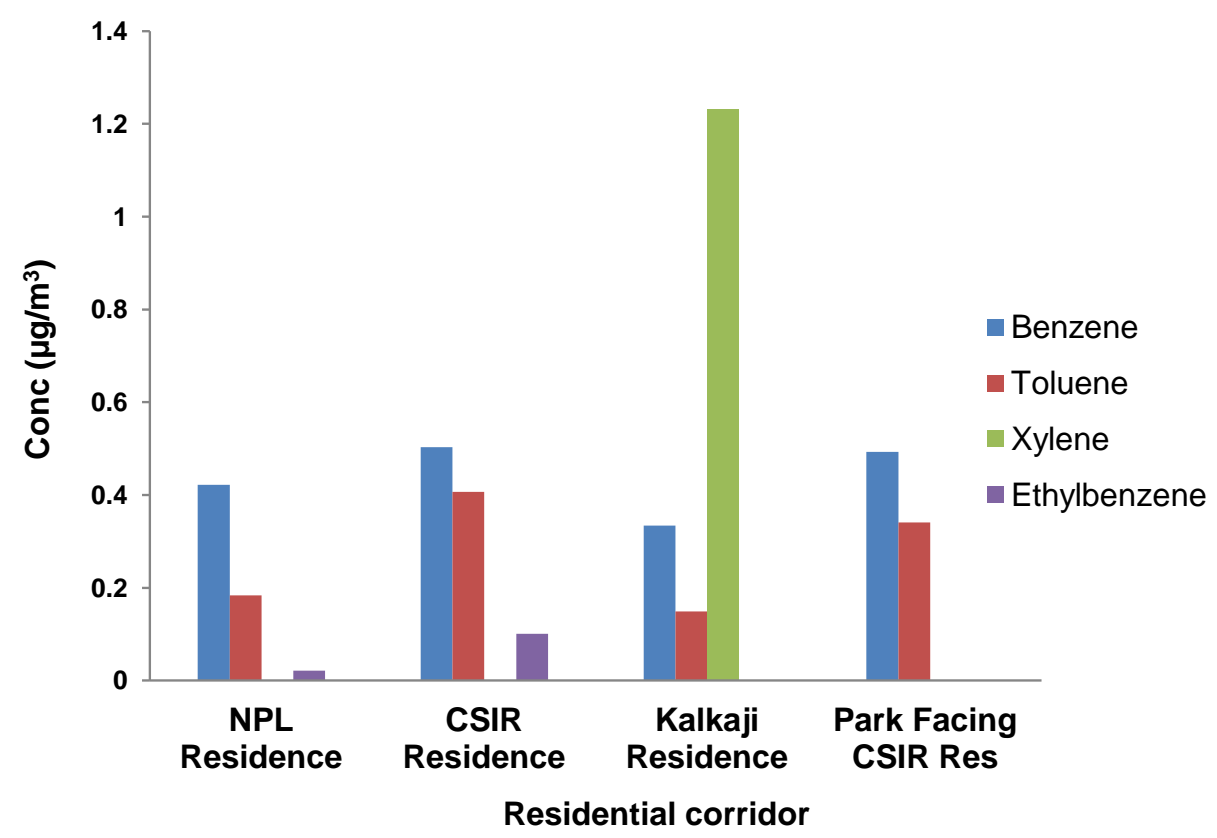

Figure 6. Variation of BTEX at NPL, CRRI and Kalkaji residence. 
To identify the major source of gasoline and diesel vehicles the adsorbent were kept directly over the petrol pumps and diesel pumps. The results of this observation showed that at diesel pump the concentration of xylene was higher and at petrol the concentration of benzene was higher which was expected. Figure 7 shows the concentration profile of BTEX at diesel and gasoline pump and it could be easily identified the presence of xylene dominating near diesel pump. The result also says that gasoline contains ethyl benzene and therefore ethylbenzene could not be detected near the locations where diesel source was more contributing (NPL Gate). From Figures 5-8 it could be easily seen that the ethylbenzene could be detected near Ashram intersection, CRRI Gate, Petrol tank and CSIR residence (same topography). This also confirms that the ethylbenzene is coming from gasoline vapour and xylene from diesel vapour. Source apportionment study using chemical mass balance (CMB) model carried out by Anjali et al. [13] [41] indicate that emissions from diesel internal combustion engines dominate in Delhi. The exhaust of gasoline and diesel automobiles contains significant concentrations of VOCs, the most important of which are benzene, 1 - 3 butadiene, $\mathrm{m} \&$ p-xylene, ethylbenzene, toluene and formaldehyde. Fuels used in vehicles are petrol (gasoline), compressed natural gas (CNG) and diesel. All taxis, buses and three wheelers use CNG as fuel. Influential species in case of diesel engine exhaust were benzene, ethylbenzene, xylenes, propane, n-decane and undecane and in case of gasoline vehicle exhaust influential species were benzene, ethylbenzene, 1,2,4- methylbenzene, 1,3,5-methylbenzene, n-hexane and 2-methylhexane.

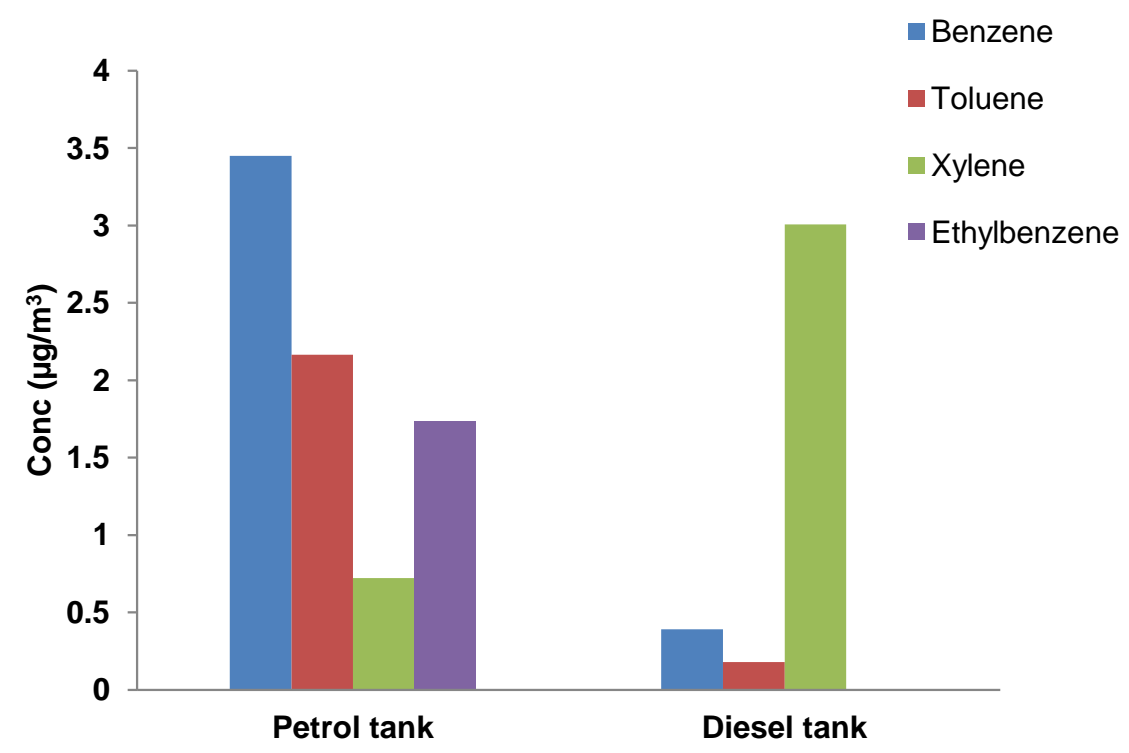

Figure 7. Concentration profile of BTEX at petrol pump and diesel pump.

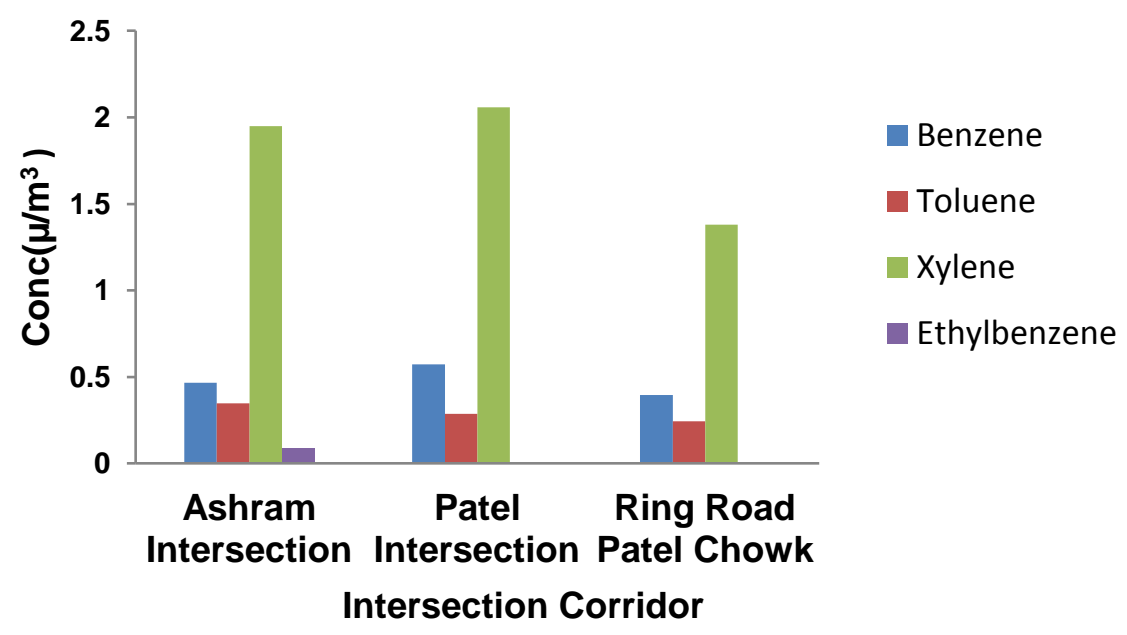

Figure 8. Variation of BTEX at intersections. 
Figure 5 shows the presence of higher concentration of benzene and ethyl benzene at CRRI gate (0.442 and $0.353 \mu \mathrm{g} \cdot \mathrm{m}^{-3}$ ). The higher conc. of benzene at CRRI gate is possible due to the presence of higher traffic density at CRRI Gate as compared to NPL Gate. But higher concentration of xylene and toluene at NPL shows the influence of presence of some industrial source near this location, like NPL is surrounded by industrial area Nariana and other industrial source. Figures 5-8 are plotted between different subcategories of locations road side corridors (CRRI and NPL gate), residential areas (NPL, CSIR and Kalkaji) and traffic intersections (Ashram Intersection, Patel Chowk intersection, ring road Patel Chowk. Relatively lower values at the residential area suggested that the air masses in these have undergone a small degree of photochemical processing. At NPL site (Figure 5), the total VOC levels were low largely because the traffic around this site was relatively low (Table 2). VOC levels were relatively high at Ashram intersections which can be attributed to high and slow moving traffic at these sites. At this frequent idling and deceleration of vehicles is a common feature [9]. Consequently, VOC levels are high at these sites as compared to sites around NPL, where traffic volume is low and free from traffic congestion. The possible reasons for the highest value at this site are: (1) high traffic density resulting in considerable congestion.

In addition, this site is located in a densely populated locality, having multi-storeyed buildings on either side of the road, creating a street canyon effect which considerably restricts pollutant dispersion; (2) has mixed traffic including which are responsible for the slowdown of traffic movement, resulting in high VOC emission by motor vehicles. (3) The main road has major intersections. Movement of vehicles through these intersections hampers the traffic on the main road resulting in frequent idling by the vehicles at these intersections. Area wise $\mathrm{B} / \mathrm{T} / \mathrm{X}$ concentrations in ambient air of Delhi at all locations followed the order near petrol pump $>$ traffic intersection > residential. The ranking of sites according to VOC concentration corresponds well with the traffic volume, and other anthropogenic activities at respective sites. The values of BTEX at all the categories were lower than the values reported by Meena et al. The lower values may be because of the diffusion based passive sampling methodology used for the adsorption of gases [42] [43]. However these values can be used for dose based study on human health (Epidemiological studies) [44].

The study was also carried out for measuring indoor air pollution at CSIR and Kalkaji Apt, and the result shows that the outdoor concentration is larger than the indoor concentration in both the locations (Figures 9-11). The comparison between CSIR and Kalkaji residential shows that the xylene is dominating Kalkaji area whereas at CSIR area xylene could not be detected (Figure 9). The interesting observation was that the xylene was present in Kalkaji, whereas ethylbenzene could not be detected, however at CSIR apt we could detect only benzene, toluene and ethylbenzene. The result is as expected because at Kalkaji area, where the adsorbent was kept is a pure residential area where in every house there is a generator which runs on diesel and therefore diesel component xylene was detected both indoor and outdoor whereas at CSIR residence the topography is totally different and this region is mainly affected by major traffic only and therefore the characteristics of pollutant present is similar to that of intersections. The presence of ethylbenzene at the residential also confirms the effect of vehicular source near residential area. As it can be seen from Table 3, some groups of monitoring stations had similar benzene to toluene ratios, which can indicate identical sources of these compounds in the atmospheric

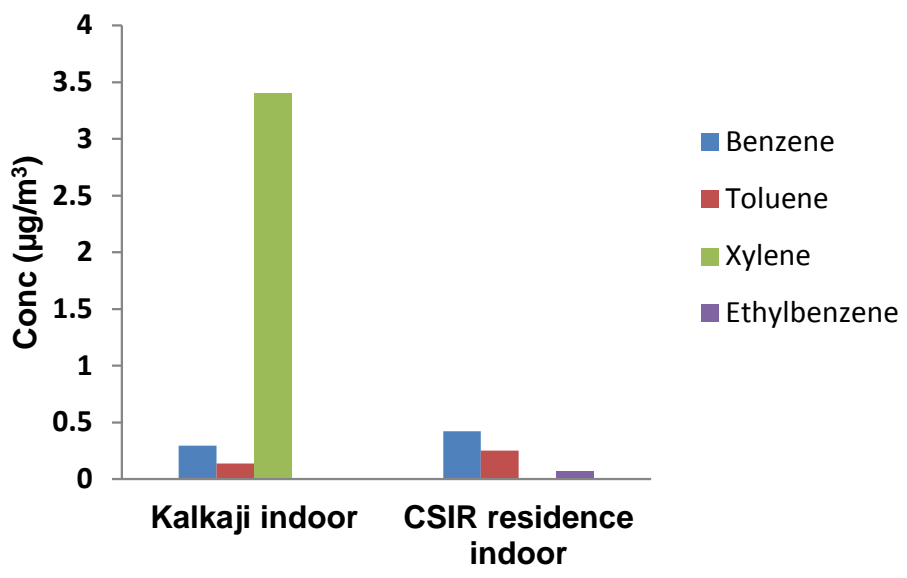

Figure 9. Variation of Indoor BTEX at Kalkaji and CSIR. 


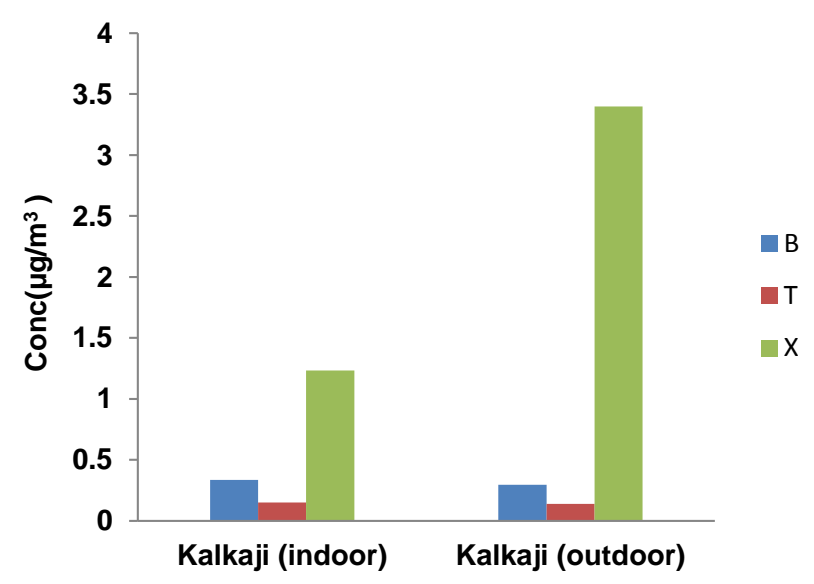

Figure 10. Variation of Indoor BTEX at Kalkaji.

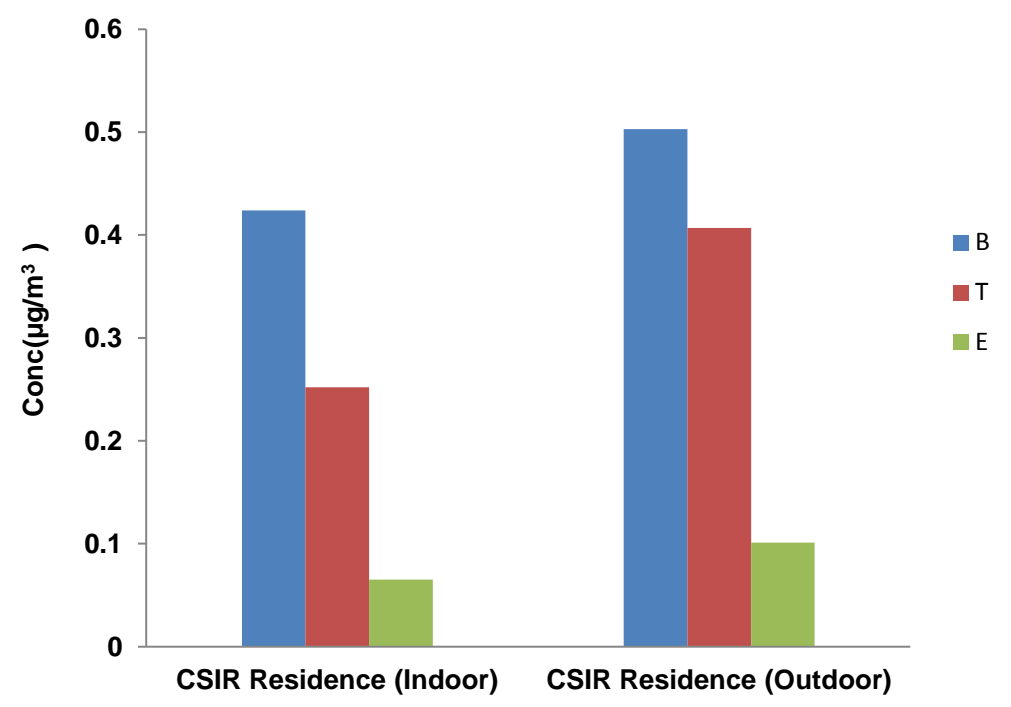

Figure 11. Variation of Indoor BTEX at CSIR.

air in those places. These results confirm that the BTEX in residence do not come from a local source and the more reactive isomers of xylene and ethylbenzene have been exposed to photochemical degradation for some time during transport of these pollutants from the surrounding areas. This is in agreement with Khoder et al. [45] who reported that the photochemical degradation of ethylbenzene and the isomeric xylene is faster than that of benzene and toluene, this degradation is favored by long transport distances. Therefore at most of the locations benzene and toluene was detected however the reactive species xylene and ethylbenzene could not be detected until and unless it is coming from some direct source.

\subsection{Concentration Ratios}

The BTEX (benzene: toluene: ethylbenzene: xylenes) concentration ratios were calculated to compare the VOCs emission sources among all sampling locations. The T/B ratios in NPL $(0.428,0.436)$ and Kalkaji $(0.446,0.470)$ were similar; both sites might be affected by similar sources. On the other hand, the T/B at Ashram was (0.747, 0.809) indicating that this site has also some common source which is different from NPL and Kalkaji area and therefore the region wise characteristics of T/B is different which might be affected by emission sources far from the sampling location, such as those associated with transportation activities, industries, gasoline emissions, diesel generators. The differences of (T/B) ratios among these places may reflect a difference between their vehicle types, fuel composition and industrial activities [45]. Some of the VOC species in the atmosphere are used as indicators of the age of the air mass and tracers for emission sources. Evaluation of toluene/benzene (T/B), 
xylene/benzene (X/B), xylene/ethylbenzene (X/E) concentration ratios is useful for characterizing the distance of vehicular emission sources and for estimating the photochemical age of the air mass. The maximum (T/B) concentration ratios were found in Ashram locations, where an intense traffic exists, whereas the minimum ones were detected in Kalkaji, which is far from the intense traffic. The ratios at both sites were nearly of the same magnitude and the (T/B) ratios were close to those obtained from automotive exhausts, thereby confirming an origin of the pollution of BTEX at both sites. Here all the locations were affected by traffic density because all the locations were only 200 to $500 \mathrm{~m}$ away from the direct traffic density. Therefore, the concentration of VOCs measured at NPL Gate is exclusively a result from diffusion and dispersion of VOCs produced from the traffic density in the surrounding areas. The time required for the transportation of the VOCs allows for significant photochemical reactions/degradation of reactive compounds such as ethylbenzene to take place, causing a reduction of ethylbenzene at NPL compared with benzene. However in our study the higher ratio of X/B at all the locations indicates xylene concentration is stable. The lower value of $X / B(0.210)$ at petrol indicates that the benzene is more in petrol and very high ratio of $\mathrm{X} / \mathrm{B}$ (7.673) indicates higher xylene concentration from diesel exhaust. So higher value of $\mathrm{X} / \mathrm{B}$ at all the locations indicates the area is affected by both petrol and diesel vehicles, however the diesel exhaust is dominating more in Delhi which is also confirmed by Anjali et al. The lower ratios of $(\mathrm{T} / \mathrm{B})$ and xylenes/benzene $(\mathrm{X} / \mathrm{B})$ are due to the faster reaction of $\mathrm{OH}$ with toluene and xylene, with respect to benzene [45]. The (T/B) ratio decreased as the distance from pollution source increased. Since benzene and other volatile aromatic hydrocarbons measured in this study were mainly from motor vehicle emissions, their ambient concentrations are likely to be correlated. Significant positive correlation coefficients between the concentrations of benzene and other BTEX species benzene can be used as a marker for other volatile aromatic hydrocarbons in heavy traffic areas.

\subsection{Seasonal Variation}

Seasonal $\mathrm{B} / \mathrm{T} / \mathrm{X} / \mathrm{E}$ concentrations for the study period at Ashram intersection varied as 0.466 to $0.827 \mu \mathrm{gm}^{-3} /$ 0.348 to $3.074 \mu \mathrm{gm}^{-3} / 0$ to $1.95 \mu \mathrm{gm}^{-3} / 0.089$ to $0.242 \mu \mathrm{g} \cdot \mathrm{m}^{-3}$ respectively. Seasonal B/T/X/E concentrations for the study period at CRRI Gate varied as 0.254 to $0.577 \mu \mathrm{gm}^{-3} / 0.023$ to $0.65 \mu \mathrm{gm}^{-3} / 0$ to $1.595 \mu \mathrm{gm}^{-3} / 0$ to 0.256 $\mu \mathrm{g} \cdot \mathrm{m}^{-3}$ respectively. Lowest concentrations were observed during summer and highest during winter season. Seasonal B/T/X concentrations at all location followed the trend summer $<$ winter. Higher concentrations values of $\mathrm{B} / \mathrm{T} / \mathrm{X}$ were observed during winter season at all locations. It could be due to low rate of dispersion, low rate of degradation and low mixing height at low temperature in winter season.

Figure 12 and Figure 13 show the seasonal variation of BTEX at CRRI gate and Ashram intersections in Delhi. The levels of VOC were relatively higher in winter as compared to spring and summer seasons due to: (1) low dispersion because of the stable atmosphere during the winter season; (2) reduction in VOC removal in

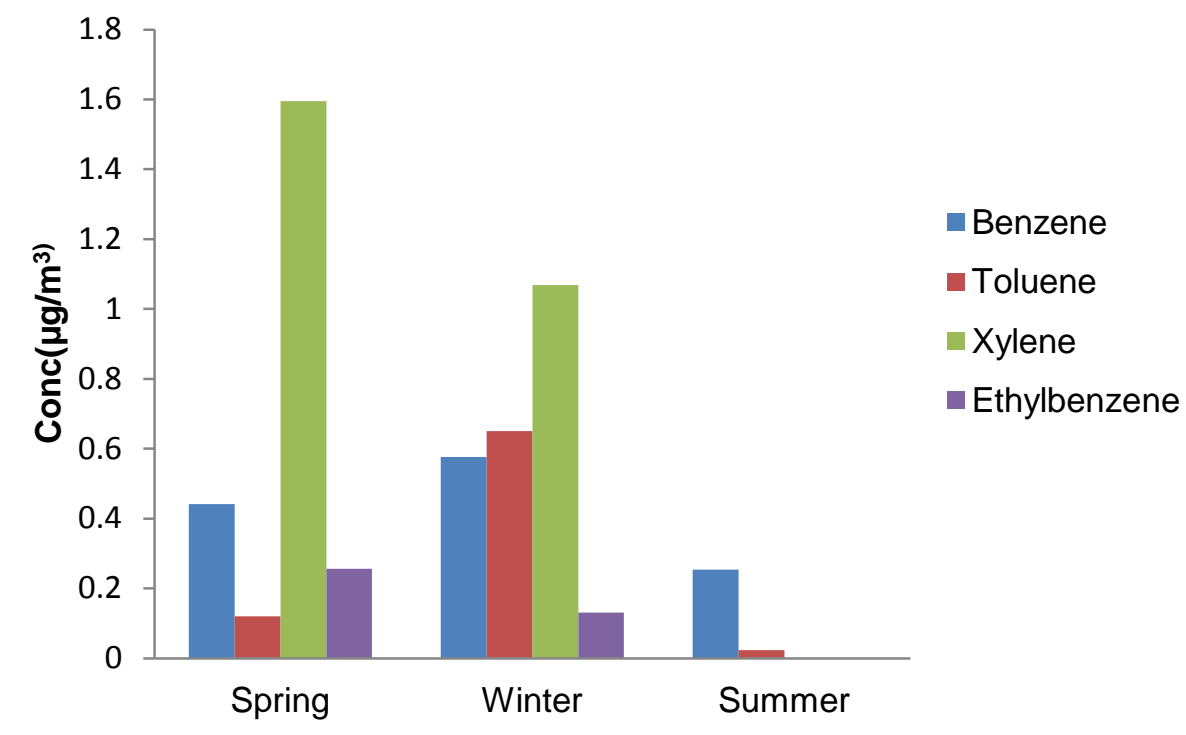

Figure 12. Seasonal variation of BTEX at CRRI gate. 


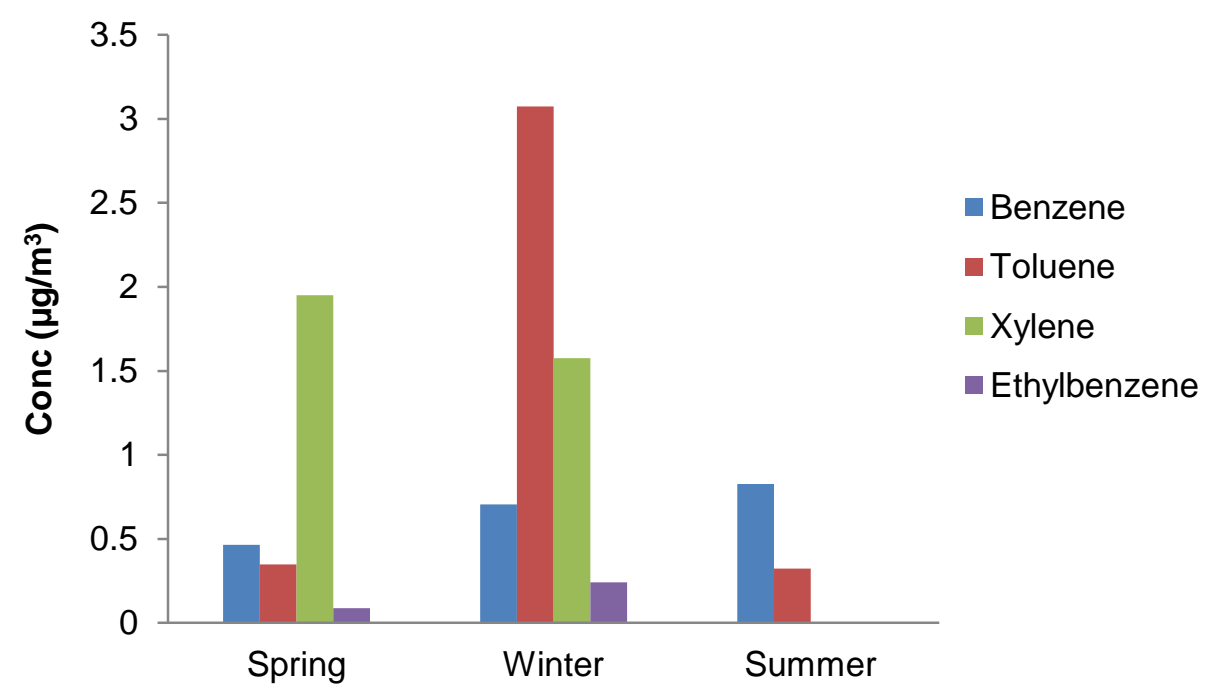

Figure 13. Seasonal variation of BTEX at Ashram intersection.

the winter season due to slow down of photochemical reactions as a result of short day length and lower solar intensity. Several researchers have reported that during winter, meteorological conditions are not suitable for $\mathrm{O}_{3}$ build-up. Relatively high solar intensity and ambient temperature are extremely suitable for the formation of tropospheric ozone formation by consuming VOC through photochemical reactions. In winter, on starting, automobiles emit more VOC because of cold engines. The concentration of benzene was lowest in summer $(0.25$ $\left.\mu \mathrm{g} / \mathrm{m}^{3}\right)$ and maximum in winter $\left(0.66 \mu \mathrm{g} / \mathrm{m}^{3}\right)$. Xylene concentration was $1.60 \mu \mathrm{g} / \mathrm{m}^{3}$ in spring and $0.05 \mu \mathrm{g} / \mathrm{m}^{3}$ in summer season. Toluene was found in the range of $0.70 \mu \mathrm{g} / \mathrm{m}^{3}$ (winter) to $0.20 \mu \mathrm{g} / \mathrm{m}^{3}$ (spring). The Fig shows that the concentrations of BTEX are lower in summer and highest in winter and spring season. This may be due to metrological factors. During summer, the dispersion is fast due to high turbulence and temperature, while during winter, due to stable condition and inversion, dispersion is less and accumulation of pollutants occurs. The lower value of benzene and toluene observed in summer could be attributed to their different lifetimes. Both aromatic compounds react only with $\mathrm{OH}$ radical during daytime, with toluene reacting significantly faster than benzene. Moreover, chemical removal of VOCs by $\mathrm{OH}$ radicals is faster in summer than in winter, as higher radiation and temperature generally facilitate their removal rates.

Hoque et al. [46] have also reported lower benzene and toluene concentrations at representative sites in Delhi as compared to the concentrations observed in the present study. Overall, the concentrations of BTEX reported in the present study are in agreement with other studies. BTEX species exhibit very clear seasonal characteristics for the study area. Observed seasonal trends can be addressed by the seasonal characteristics of the prevailing meteorology, variations in the source strength and, most importantly, the availability of $\mathrm{OH}$ radical and insolation that take care of the removal process of the VOC species from the atmosphere. The meteorology in Delhi shows an explicit winter and summer characteristics. In the winter months calm conditions and high stability of the atmosphere prevails, which hinder the pollutants from dissipating faster. Temperature inversion, which is a common phenomenon in the winter months and low mixing heights do restrict dilution process of the pollutants. Thus in the winter months the pollutants generally show a higher level of concentration. An enhanced emission of aromatics is also due to cold start of gasoline powered vehicles in the winter months. In contrast, the summer months in Delhi experience higher mixing height and an unstable atmosphere.

Meteorologically these factors favor to better mixing and easy dissipation of the pollutants leading to their lower levels in the atmosphere. Delhi records more insolation during summers which helps in the photolysis of species like ozone, aldehydes etc., and leading to the formation of $\mathrm{OH}$ radical. Thus in the summer months high level of $\mathrm{OH}$ concentration could prevail in the atmosphere of Delhi, which plays the key role in the atmospheric clean up and degradation process of the aromatic VOCs. The seasonal profiles were almost similar at all the sites. At all the sites the higher concentration of toluene and xylene is indicative of some additional source in winter that enhances evaporation of toluene from industries like paints and varnishes, printing press and vehicular service stations. The high toluene concentrations may be due to the presence of waste dumping, landfill site and incineration plants near this area [47]. 


\section{Conclusions}

In this study spatial and seasonal variation of BTEX was measured at different locations in Delhi. The results confirm that aromatic concentrations in the ambient air of gas stations were appreciably higher than the average values in locations with high vehicular flux but ratios of benzene/toluene are slightly different. Xylene was dominant in the entire sampling sites except residential areas. The average concentration of benzene was highest at petrol pump $3.5 \mu \mathrm{g} / \mathrm{m}^{3}$ however at all other sampling sites it was in the range of 0.294 to $0.712 \mu \mathrm{g} / \mathrm{m}^{3}$. The concentration was in the order of petrol filling stations $>$ intersections $>$ road side corridors $>$ residence.

The BTEX (benzene: toluene: ethylbenzene: xylenes) concentration ratios were calculated to compare the VOCs emission sources among all sampling locations. The T/B ratios at NPL $(0.428,0.436)$ and Kalkaji (0.446, 0.470 ) were similar; both sites might be affected by similar sources. On the other hand, the T/B at Ashram was $(0.747,0.809)$ indicating that this site has also some common source which is different from NPL and Kalkaji area and therefore the region wise characteristics of $\mathrm{T} / \mathrm{B}$ is different which might be affected by emission sources far from the sampling location, such as those associated with transportation activities, industries, gasoline emissions, diesel generators. The highest T/B ratio was observed at locations: Ashram Intersection, CSIR Residence (Outdoor), Ring Road Patel Chowk, Park Facing Residence and Petrol Pump which were 0.747, 0.809, 0.618, 0.692 and 0.628, respectively, which were larger than 0.6 indicating a strong contribution from vehicular emissions with a certain degree of photochemical process. The topography of this location is almost similar as all the locations are either at intersection or very close to major intersection. The T/B values were almost similar suggesting the common source of pollution i.e. vehicular/ traffic. These kinds of VOCs have been reported to be emitted from automobiles. The resemblance of T/B ratios of the roadside and intersection sites was because these VOCs might be emitted from vehicles and dilute due to advection and/or diffusion uniformly in the environment without considerable influence from stationary sources.

The concentration levels of BTEX showed seasonal variations with a vivid winter maximum. Lowest concentrations were observed during summer and highest during winter season. Seasonal B/T/X concentrations at all location followed the trend summer < winter. Higher concentrations values of B/T/X were observed during winter season at all locations. It could be due to low rate of dispersion, low rate of degradation and low mixing height at low temperature in winter season. The meteorology of Delhi and reactivity behaviour of BTEX could be responsible for the seasonal variation. The results of this study showed distinct seasonal and spatial variability in atmospheric BTEX concentrations at sampling sites. Their spatial distribution showed high differences between high-traffic and residential areas and also pointed to traffic as the main emission source of these compounds. Information on VOC concentrations in ambient air for Indian cities is lacking. Therefore, it is a matter of concern that government should take immediate action to control VOCs especially BTEX in Delhi city. The data obtained in this study will be helpful in making regulations of toluene and xylene which is of equal important VOCs as compared to benzene. Till now there is no permissible standard for toluene and Xylene. Therefore the study will help in regulating these VOCs standards.

\section{References}

[1] Right to Clean Air Campaign, Centre for Science and Environment (2012) Benzene Levels High Again: Need Action. 41, 1-8.

[2] Agency for Toxic Substances and Disease Registry (ASTDR) (2007) Public Health Statement for Benzene. August 2007CAS\#: 71-43-2.

[3] Roychoudhury, S. (2014) Exclusive: Delhi Morning Walkers Inhale Killer Benzene and Carbon Monoxide. India Today, New Delhi, February 6.

[4] Saxena, P. and Ghosh, C. (2012) A Review of Assessment of Benzene, Toluene, Ethylbenzene and Xylene (BTEX) Concentration in Urban Atmosphere of Delhi. International Journal of the Physical Sciences, 7, 850-860.

[5] Zhang, J., Sun, Y., Wu, F., Sun, J. and Wang, Y. (2014) The Characteristics, Seasonal Variation and Source Apportionment of VOCs at Gongga Mountain, China. Atmospheric Environment, 88, 297-305. http://dx.doi.org/10.1016/j.atmosenv.2013.03.036

[6] Shen, X., Zhao, Y., Chen, Z. and Huang, D. (2013) Heterogeneous Reactions of Volatile Organic Compounds in the Atmosphere. Atmospheric Environment, 68, 297-314. http://dx.doi.org/10.1016/j.atmosenv.2012.11.027

[7] Pang, Y., Fuentes, M. and Rieger, P. (2014) Trends in the Emissions of Volatile Organic Compounds (VOCs) from Light-Duty Gasoline Vehicles Tested on Chassis Dynamometers in Southern California. Atmospheric Environment, 83, 127-135. http://dx.doi.org/10.1016/j.atmosenv.2013.11.002 
[8] Srivastava, A., Joseph, A.E. and Devotta, S. (2006) Volatile Organic Compounds in Ambient air of Mumbai-India. Atmospheric Environment, 40, 892-903. http://dx.doi.org/10.1016/j.atmosenv.2005.10.045

[9] http://indiatoday.intoday.in/story/delhi-traffic-jams-fuel-wastage-pollution-crri-report/1/409292.html

[10] Correa, S.M., Arbilla, G., Marques, M.R.C. and Oliveira, K.M.P.G. (2012) The Impact of BTEX Emissions from Gas Stations into the Atmosphere. Atmospheric Pollution Research, 3, 163-169. http://dx.doi.org/10.5094/APR.2012.016

[11] Garzon, J.P., Huertas, J., Magana, M., Huertas, M.E., Cardenas, B., Watanabe, T., Maeda, T., Wakamatsu, S. and Blanco, S. (2015) Volatile Organic Compounds in the Atmosphere of Mexico City. Atmospheric Environment, 119, 415-429. http://dx.doi.org/10.1016/j.atmosenv.2015.08.014

[12] Chan, C.Y., Chan, L.Y., Wang, X.M., Liu, Y.M., Lee, S.C., Zou, S.C., Sheng, G.Y. and Fu, J.M. (2002) Volatile Organic Compounds in Roadside Microenvironments of Metropolitan Hong Kong. Atmospheric Environment, 36, 20392047. http://dx.doi.org/10.1016/S1352-2310(02)00097-3

[13] Srivastava, A., Joseph, A.E., More, A. and Patil, S. (2005) Emissions of VOCs at Urban Petrol Retail Distribution Centres in India (Delhi and Mumbai). Environmental Monitoring and Assessment, 109, 227-242. http://dx.doi.org/10.1007/s10661-005-6292-z

[14] Pankow, J.F., Luo, W., Bender, D.A., Isabelle, L.M., Hollingsworth, J.S., Chen, C., Asher, W.E. and Zogorski, J.S. (2003) Concentrations and Co-Occurrence Correlations of 88 Volatile Organic Compounds (VOCs) in the Ambient Air of 13 Semi-Rural to Urban Locations in the United States. Atmospheric Environment, 37, 5023-5046. http://dx.doi.org/10.1016/j.atmosenv.2003.08.006

[15] World Health Organization and Air Quality Guidelines for Europe (2000) World Health Organization, 2000. Air Quality Guidelines for Europe. 2nd Edition, WHO Regional Office for Europe, Copenhagen, WHO Regional Publication, European Series No. 91.

[16] IARC (1987) IARC Monographs on the Evaluation of Carcinogenic Risks to Humans. Overall Evaluations of Carcinogenicity: An Updating of IARC Monographs Volume 1-42, Suppl 7. IARC, Lyon.

[17] OSHA (1977) Occupational Exposure to Benzene; Emergency Temporary Standards, Hearing May 3, Part IV, Fed. Reg. 42, 22516-22529.

[18] Agency for Toxic Substances and Disease Registry (ATSDR) (1997) Toxicological Profile for Benzene (Draft). U.S. Public Health Service, U.S. Department of Health and Human Services, Atlanta.

[19] Wadge, A. (1997) Benzene-Toxicology, National Environmental Health Forum Monographs, Air Series, No. 2, 18-20.

[20] IARC (1987) IARC Monographs on the Evaluation of Carcinogenic Risks to Humans. Overall Evaluation of CARCINOGENICITY: An Updating of IARC Monographs Volumes 1 to 42, Suppl 7, World Health Organization, International Agency for Research on Cancer, Lyons, 38-74.

[21] Spyros, P. K., Costas, P.L., Paylos, K.A. and Georgios, A.P. (2007) Assessment and Prediction of Exposure to Benzene of Filling Station Employees. Atmospheric Environment, 41, 9555-9569. http://dx.doi.org/10.1016/j.atmosenv.2007.08.030

[22] Chauhan, S.K., Saini, N. and Yadav, V.B. (2014) Recent Trends of Volatile Organic Compounds in Ambient Air \& its Health Impacts: A Review. International Journal for Technological Research in Engineering, 1, 667-678.

[23] PARIVESH (2005) Hazardous Air Pollutants, Central Pollution Control Board, Ministry of Environment and Forests.

[24] Cheng, L., Fu, L., Angle, R.P. and Sandhu, H.S. (1997) Seasonal Variations of Volatile Organic Compounds in Edmonton: Alberta. Atmospheric Environment, 31, 239-246. http://dx.doi.org/10.1016/1352-2310(96)00170-7

[25] Khoder, M.I. (2007) Ambient Levels of Volatile Organic Compounds in the Atmosphere of Greater Cairo. Atmospheric Environment, 41, 554-566. http://dx.doi.org/10.1016/j.atmosenv.2006.08.051

[26] Srivastava, A. (2004) Source Apportionment of Ambient VOCS in Mumbai City. Atmospheric Environment, 38, 68296843. http://dx.doi.org/10.1016/j.atmosenv.2004.09.009

[27] Zhang, Y., Wang, X., Zhang, Z., Lü, S., Shao, M., Lee, F.S.C. and Yu, J. (2013) Species Profiles and Normalized Reactivity of Volatile Organic Compounds from Gasoline Evaporation in China. Atmospheric Environment, 79, 110-118. http://dx.doi.org/10.1016/j.atmosenv.2013.06.029

[28] Kumar, A. and Víden, I. (2007) Volatile Organic Compounds: Sampling Methods and Their Worldwide Profile in Ambient Air. Environmental Monitoring and Assessment, 131, 301-321. http://dx.doi.org/10.1007/s10661-006-9477-1

[29] Uchiyama, S., Asai, M. and Hasegawa, S. (1999) A Sensitive Diffusion Sampler for the Determination of Volatile Organic Compounds in Ambient Air. Atmospheric Environment, 33, 1913-1920. http://dx.doi.org/10.1016/S1352-2310(98)00208-8

[30] Colman Lerner, J.E., Sanchez, E.Y., Sambeth, J.E. and Porta, A.A. (2012) Characterization and health risk assessment of VOCs in occupational environments in Buenos Aires, Argentina. Atmospheric Environment, 55, 440-447. http://dx.doi.org/10.1016/j.atmosenv.2012.03.041 
[31] Hakim, M., Barash, B.O., Peled, N., Phillips, M., Amann, A. and Haick, H. (2012) Volatile Organic Compounds of Lung Cancer and Possible Biochemical Pathways. Chemical Reviews, 112, 5949-5966. http://dx.doi.org/10.1021/cr300174a

[32] Zabiegała, B., Urbanowicz, M., Szymanska, K. and Namiesnik, J. (2010) Application of Passive Sampling Technique for Monitoring of BTEX Concentration in Urban Air: Field Comparison of Different Types of Passive Samplers. Journal of Chromatographic Science, 48, 167-175. http://dx.doi.org/10.1093/chromsci/48.3.167

[33] Azari, M.R., Nejad, M.R.M. and Motesadi, S. (2008) A New Sampler and Analysis Method for BTEX in Ambient Air. Tanaffos, 7, 47-52.

[34] CSIR-Central Road Research Institute, India, Annual Report, 2013-2014.

[35] Sehgal, M., Suresh, R., Sharma, V.P. and Gautam, S.K. (2011) Variations in Air Quality at Filling Stations, Delhi, India. International Journal of Environmental Studies, 68, 845-849. http://dx.doi.org/10.1080/00207233.2012.620320

[36] Correa, S.M., Arbilla, G., Marques, M.R.C. and Oliveira, K.M.P.G. (2012) The Impact of BTEX Emissions from Gas Stations into the Atmosphere. Atmospheric Pollution Research, 3, 163-169. http://dx.doi.org/10.5094/APR.2012.016

[37] http://blog.heart.org/homes-near-highways-may-up-heart-disease-risks/

[38] Rad, H.D., Babaei, A.A., Goudarzi, G., Angali, K.A., Ramezani, Z. and Mohammadi, M.M. (2014) Levels and Sources of BTEX in Ambient Air of Ahvaz Metropolitan City. Air Quality, Atmosphere \& Health, 7, 515-524. http://dx.doi.org/10.1007/s11869-014-0254-y

[39] Zhang, Y., Mua, Y., Liang, P., Xu, Z., Liu, J., Zhang, H., Wang, X., Gao, J., Wang, S., Chai, F. and Mellouki, A. (2012) Atmospheric BTEX and Carbonyls during Summer Seasons of 20082010 in Beijing. Atmospheric Environment, 59, 186-191. http://dx.doi.org/10.1016/j.atmosenv.2012.06.030

[40] Lan, T.T.N. and Binh, N.T.T. (2012) Daily Roadside BTEX Concentrations in East Asia Measured by the Lanwatsu, Radiello and Ultra I SKS Passive Samplers. Science of the Total Environment, 441, 248-257. http://dx.doi.org/10.1016/j.scitotenv.2012.08.086

[41] Srivastava, A., Joseph, A.E. and Devotta, S. (2006) Volatile Organic Compounds in Ambient Air of Mumbai-India. Atmospheric Environment, 40, 892-903. http://dx.doi.org/10.1016/j.atmosenv.2005.10.045

[42] Martin, N.A., Leming, E.J., Henderson, M.H., Lipscombe, R.P., Black, J.K. and Jarvis, S.D. (2010) Verification of Diffusive and Pumped Samplers for Volatile Organic Compounds Using a Controlled Atmosphere Test Facility. Atmospheric Environment, 44, 3378-3385. http://dx.doi.org/10.1016/j.atmosenv.2010.06.014

[43] Walgraeve, C., Demeestere, K., Dewulf, J., Huffel, K.V. and Langenhove, H.V. (2011) Uptake Rate Behaviour of Tube-Type Passive Samplers for Volatile Organic Compounds under Controlled Atmospheric Conditions. Atmospheric Environment, 45, 5872-5879. http://dx.doi.org/10.1016/j.atmosenv.2011.06.069

[44] Walgraeve, C., Demeestere, K., Dewulf, J., Huffel, K.V. and Langenhove, H.V. (2011) Diffusive Sampling of 25 Volatile Organic Compounds in Indoor Air: Uptake Rate Determination and Application in Flemish Homes for the Elderly. Atmospheric Environment, 45, 5828-5836. http://dx.doi.org/10.1016/j.atmosenv.2011.07.007

[45] Khoder, M.I. (2007) Ambient Levels of Volatile Organic Compounds in the Atmosphere of Greater Cairo. Atmospheric Environment, 41, 554-566. http://dx.doi.org/10.1016/j.atmosenv.2006.08.051

[46] Hoque, R.R., Khillare, P.S., Agarwal, T., Shridhar, V. and Balachandran, S. (2008) Spatial and Temporal Variation of BTEX in the Urban Atmosphere of Delhi, India. Science of the Total Environment, 392, 30-40. http://dx.doi.org/10.1016/j.scitotenv.2007.08.036

[47] Kima, K.-H. and Kim, M.-Y. (2002) The Distributions of BTEX Compounds in the Ambient Atmosphere of the Nan-Ji-Do Abandoned Landfill Site in Seoul. Atmospheric Environment, 36, 2433-2446. http://dx.doi.org/10.1016/S1352-2310(02)00191-7 